\title{
Bacteroides endodontalis sp. nov., an Asaccharolytic Black- Pigmented Bacteroides Species from Infected Dental Root Canals
}

\author{
T. J. M. van STEENBERGEN, ${ }^{1 *}$ A. J. VAN WINKELHOFF, ${ }^{1}$ D. MAYRAND ${ }^{2}$ D. GRENIER, ${ }^{2}$ AND J. DE GRAAFF ${ }^{1}$ \\ Research Group for Commensal Infections, Departments of Medical and Oral Microbiology, Vrije Universiteit, 1007 MC \\ Amsterdam, The Netherlands, ${ }^{1}$ and Groupe de recherche en écologie buccale, Ecole de médecine dentaire, Université
} Laval, Québec, Canada GIK $7 P 4^{2}$

\begin{abstract}
A new species, Bacteroides endodontalis, is proposed for black-pigmented asaccharolytic Bacteroides strains that have negligible deoxyribonucleic acid homology with either Bacteroides gingivalis or Bacteroides asaccharolyticus. Strain HG370 (= ATCC 35406$)$ is the type strain. Unlike $B$. gingivalis, $B$. endodontalis does not agglutinate sheep erythrocytes or produce phenylacetic acid. $B$. endodontalis resembles $B$. asaccharolyticus physiologically but can be distinguished by its lower deoxyribonucleic acid guanine-plus-cytosine content ( 50 versus 53 to $54 \mathrm{~mol} \%$ ), by its serological reactions, by its electrophoretic patterns of proteins, and possibly by its menadione requirement.
\end{abstract}

The classification of black-pigmented Bacteroides strains, which were formerly classified as Bacteroides melaninogenicus, has been much improved recently, and many new species have been proposed, mainly on the basis of deoxyribonucleic acid (DNA) homology studies (1, 2, 5-7, 13, 19, 20). The following two asaccharolytic species have been described previously: Bacteroides asaccharolyticus (2) and Bacteroides gingivalis (1). Strains of $B$. asaccharolyticus are mostly from nonoral sources, whereas strains of $B$. gingivalis are mainly from periodontal pockets. $B$. gingivalis can be easily distinguished from $B$. asaccharolyticus by its ability to agglutinate erythrocytes (15), to produce phenylacetic acid (8), and to demonstrate a strong trypsin-like activity (14).

Previously, we reported (19) that two asaccharolytic black-pigmented Bacteroides strains that were isolated by Sundqvist (G. Sundqvist, Ph.D. thesis, University of Umea, Umea, Sweden, 1976) from dental root canals had negligible DNA homology with either $B$. gingivalis or $B$. asaccharolyticus. In this paper we describe DNA hybridization studies which showed that these strains and another isolate from an infected dental root canal form a distinct DNA homology group. We propose a new species for these strains, Bacteroides endodontalis; strain $\mathrm{HG} 370(=\mathrm{ATCC} 35406)$ is the type strain of this species.

\section{MATERIALS AND METHODS}

Bacterial strains. The strains which we used are listed in Table 1. Strain $\mathrm{HG} 370^{\mathrm{T}}$ ( $\mathrm{T}=$ type strain) was isolated along with anaerobic streptococci from an infected root canal with a very large area of periapical destruction. The strains were maintained on sheep blood agar plates (Oxoid no. 2 agar supplemented with $0.05 \%$ hemin and $0.01 \%$ menadione) in an atmosphere containing $80 \% \mathrm{~N}_{2}, 10 \% \mathrm{CO}_{2}$, and $10 \% \mathrm{H}_{2}$.

Physiological characteristics. The fermentation and biochemical tests, as well as the procedures for extraction and methylation of volatile and nonvolatile fatty acids, were done according to the methods outlined in the Anaerobe Laboratory Manual (4) and by the Minitek anaerobic system (BBL Microbiology Systems, Cockeysville, Md.). The compounds used in the fermentation assays were glucose, sucrose, lactose, cellobiose, mannose, arabinose, maltose, rhamnose, trehalose, xylose, raffinose, sorbitol, salicin, mannitol, and glycerol. Menadione requirement was deter-

* Corresponding author. mined by using BM agar plates (18) without menadione for three passages.

The enzymatic activities of the strains were studied with the API ZYM system (API Produits de Laboratoire Ltee., St.-Laurent, Canada) by using growth conditions and test procedures which have been described previously (14). Hemagglutination assays using sheep erythrocytes were performed in titer plates as described by Mayrand et al. (10), except that no reducing agent was added, and by the slide test described by Slots and Genco (15). Protease activity (Azocoll) was measured as previously described (9). Collagenase activity was determined by two methods; the first involved growth in broth in the presence of collagen (16), whereas the second measured the collagenolytic activity of washed cells as described by Gisslow and McBride (3). Polyacrylamide gel electrophoresis of soluble proteins was done according to the methods and procedures described by Moore et al. (11).

Isolation of DNA. Unlabeled DNA was isolated from cells lysed with sodium dodecyl sulfate or from cells lysed mechanically with a Vibrogen cell mill (Bühler, Tübingen, Federal Republic of Germany), as described previously (17). Tritiated DNA was isolated from Sarcosyl-lysed cells by means of $\mathrm{CsCl}$ density gradient centrifugation (19).

Determination of DNA base composition and DNA homology. DNA base composition was determined by the buoyant density method, and the amount of DNA-DNA hybridization was determined by the S1 nuclease method essentially as described previously (19).

Indirect fluorescent antibody staining. The procedures used for antiserum production in rabbits, conjugate preparation (goat immunoglobulin monospecific for rabbit immunoglobulin labeled with fluorescein isothiocyanate isomer I [BBL]), and actual assay were those described by Mouton et al. (12). Fluorescence of single cells was graded as follows: $4+$, brilliant fluorescence with good cell envelope definition, center of cell dark; $3+$, moderate fluorescence with good cell envelope definition, center of cell dark; $2+$, faint fluorescence, single cells visible with no definition of cell envelope; $1+$, bare fluorescence, single cells not distinguishable; 0 , no visible staining of bacteria.

\section{RESULTS}

Three asaccharolytic, black-pigmented Bacteroides strains from infected dental root canals with periapical 
TABLE 1. Strains used in this study

\begin{tabular}{lcl}
\hline \multicolumn{1}{c}{ Strain } & Source $^{a}$ & \multicolumn{1}{c}{ Site of isolation } \\
\hline B. endodontalis sp. nov. & & \\
HG181 (= H11 a-e) & 1 & Infected root canal \\
HG182 (= BN11 a-f) & 1 & $\begin{array}{l}\text { Infected root canal } \\
\text { Infected root canal }\end{array}$ \\
HG370 ${ }^{\mathrm{T}}(=$ ATCC 35406$)$ & 2 & \\
B. asaccharolyticus & 3 & Human feces \\
HG78 (= B536) & 3 & Empyema \\
HG107 $\left(=\right.$ ATCC $\left.25206^{\mathrm{T}}\right)$ & 3 & Dental plaque \\
HG364 (= BM4) & 4 & Human leg wound \\
HG111 (= ATCC 27067) & 5 & \\
B. gingivalis & 3 & Clinical specimen \\
HG66 (= W83) & 6 & Human gingival sulcus \\
HG372 &
\end{tabular}

${ }^{a}$ Sources: 1, G. Sundqvist, University of Umea, Umea, Sweden; 2, our isolate; $3, \mathrm{H}$. N. Shah, London Hospital Medical College, London, United Kingdom; 4, G. H. Bowden, University of Winnipeg, Winnipeg, Canada; 5, E. C. S. Chan, McGill University, Montreal, Canada; 6, J. Slots, State University of New York, Buffalo.

destruction were studied. A DNA analysis of these strains showed a guanine-plus-cytosine content of 49.6 to $50.2 \mathrm{~mol} \%$ (Table 2). DNA-DNA hybridization experiments showed little or no homology of the DNAs of these three strains with reference DNAs of $B$. asaccharolyticus and $B$. gingivalis. The three strains formed a distinct DNA homology group with mutual DNA hybridization values of $87 \%$ or more (Table 2). From these results we concluded that these strains should be placed in a separate species, for which we propose the name Bacteroides endodontalis (en.do.don'ta.lis. Gr.prep.endon within; Gr.n.odon tooth; endodontalis within teeth). The cells of $B$. endodontalis strains are obligately anaerobic, nonsporeforming, nonmotile, gram negative, and rod shaped. Cells grown in broth are 0.4 to 0.6 by 1.0 to 1.5 $\mu \mathrm{m}$. The organisms require hemin and vitamin $\mathrm{K} 1$ or menadione for growth. Colonies grow slowly on blood agar plates. After $48 \mathrm{~h}$ of incubation colonies are 1 to $2 \mathrm{~mm}$ in diameter, low convex, circular, smooth, and entire. Dark brown or black pigmentation develops only after incubation for more than 7 days at $37^{\circ} \mathrm{C}$. When hemolyzed sheep blood is used, pigmentation develops within 3 days. Hemolysis is visible on

TABLE 2. Guanine-plus-cytosine contents and relative levels of hybridization of DNAs from asaccharolytic black-pigmented Bacteroides strains with reference DNAs from strains of $B$. endodontalis, $B$. asaccharolyticus, and $B$. gingivalis

\begin{tabular}{|c|c|c|c|c|}
\hline \multirow[t]{2}{*}{$\begin{array}{c}\text { Source of unlabeled } \\
\text { DNA }\end{array}$} & \multirow{2}{*}{$\begin{array}{l}\text { Guanine-plus- } \\
\text { cytosine content } \\
(\mathrm{mol} \%)\end{array}$} & \multicolumn{3}{|c|}{$\begin{array}{c}\text { Relative hybridization (\%) } \\
\text { with labeled DNA from } \\
\text { strain: }\end{array}$} \\
\hline & & HG181 & $\mathrm{HG} 107^{\mathrm{T}}$ & HG66 \\
\hline \multicolumn{5}{|l|}{ B. endodontalis } \\
\hline HG181 & 50.0 & 100 & 12 & $0^{a}$ \\
\hline HG182 & 50.2 & 87 & 20 & $0^{a}$ \\
\hline $\mathrm{HG} 30^{\mathrm{T}}$ & 49.6 & $9 ?$ & 19 & 0 \\
\hline \multicolumn{5}{|l|}{ B. asaccharolyticus } \\
\hline HG78 & 54.2 & 38 & 83 & $0^{a}$ \\
\hline $\mathrm{HG} 107^{\mathrm{T}}$ & 53.0 & 15 & 100 & $22^{i}$ \\
\hline HG364 & 54.3 & 31 & 87 & 0 \\
\hline \multicolumn{5}{|l|}{ B. gingivalis } \\
\hline HG66 & 48.2 & 25 & 9 & $100^{a}$ \\
\hline $\mathrm{HG} 372^{\mathrm{T}}$ & 49.2 & 3 & 0 & 68 \\
\hline
\end{tabular}

\footnotetext{
${ }^{a}$ Data from reference 19 .
}

blood agar plates after incubation for $24 \mathrm{~h}$ in air. The organisms do not ferment any of the sugars listed above. The final $\mathrm{pH}$ in broth containing glucose is 6.8 to 7.2. Acetic, propionic, butyric, isobutyric, and isovaleric acids are produced. Phenylacetic acid is not produced. No collagenolytic or proteolytic activity is detected, except for a positive gelatinase reaction. API ZYM tests show no trypsin-like activity and strong acid and alkaline phosphatase and phosphoamidase activities. The organisms do not produce hemagglutin or catalase; indole and $\mathrm{H}_{2} \mathrm{~S}$ are produced. Arginine is hydrolyzed; starch and esculin are not hydrolyzed. Nitrate is not reduced.

The protein patterns of the three strains which we studied were not identical, although similar bands were present throughout the gel. However, the general pattern of these three strains was very different from the patterns of $B$. asaccharolyticus and B. gingivalis isolates (Fig. 1). A serological analysis using an indirect fluorescence antibody staining method showed that all three isolates react poorly or not at all (reactions of 0 or $1+$ with an antiserum diluted 1 in 20 ) with antisera directed against $B$. gingivalis or $B$. asaccharolyticus. The homologous strains and antisera gave results of $3+$ or $4+$ (with an antiserum diluted 1 in 640). These data indicate that the three strains which we studied do not share common antigens with $B$. gingivalis or $B$. asaccharolyticus.

The type strain of $B$. endodontalis is strain HG370 (= ATCC 35406).

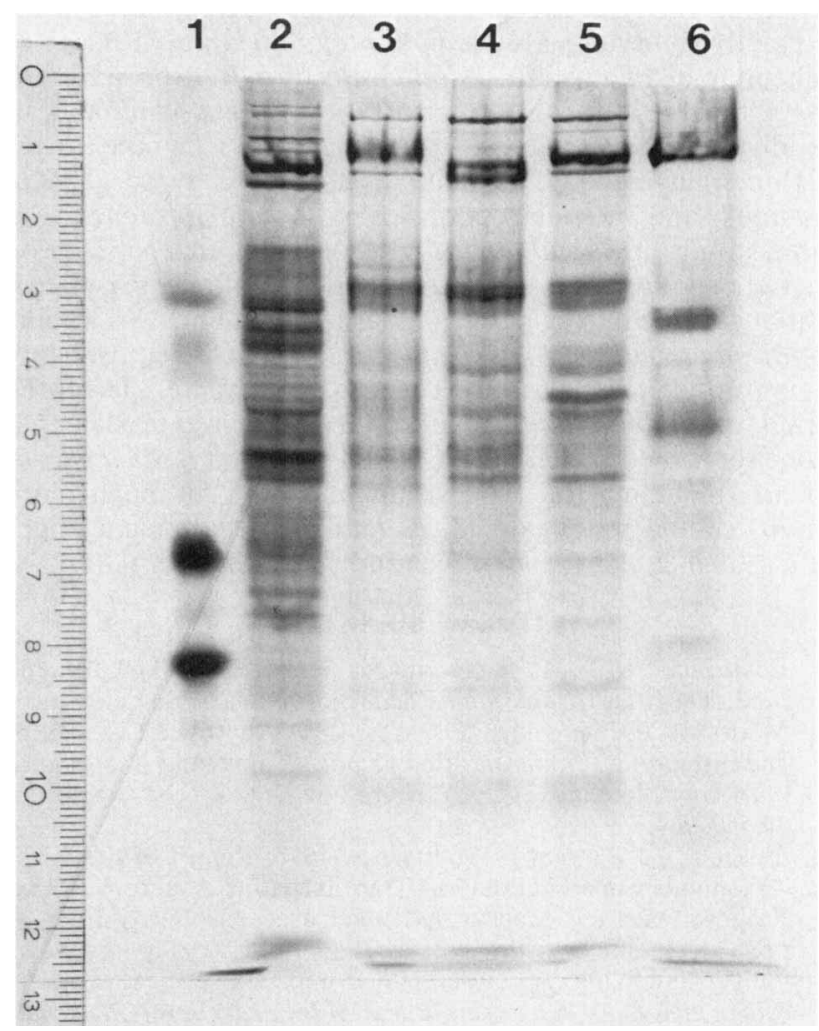

FIG. 1. Soluble protein patterns. Lane 1, Standard mixture of bovine serum albumin, carbonic anhydrase, chicken egg albumin, and lactalbumin; lane 2, B. asaccharolyticus strain $\mathrm{HG} 107^{\mathrm{T}}$; lane 3,

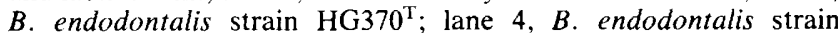
HG182; lane $5, B$. endodontalis strain HG181; lane $6, B$. gingivalis strain $\mathrm{HG}_{372^{\mathrm{T}}}$ 


\section{DISCUSSION}

It has been shown that most oral asaccharolytic blackpigmented Bacteroides strains belong to $B$. gingivalis and that most of the nonoral or "clinical" isolates belong to $B$. asaccharolyticus $(1,19)$. However, there are exceptions; strain HG364, which was isolated from dental plaque, was identified as $B$. asaccharolyticus. This strengthens the conclusion that an identification based only on isolation site is inappropriate.

Asaccharolytic black-pigmented Bacteroides strains HG181 and HG182 were originally isolated by Sundqvist (Ph. D. thesis) from dental root canals; his description is fully consistent with the description given in this paper.

In a previous paper (19), we reported that strains HG181 and $\mathrm{HG} 182$, which were isolated from dental root canals, were different from both $B$. gingivalis and $B$. asaccharolyticus on the basis of DNA-DNA hybridization. It may be significant that the three strains of $B$. endodontalis were all isolated from dental root canals with periapical destruction. Further research will be necessary to determine the prevalence of $B$. endodontalis in dental root canals, in other samples from oral cavities, and in nonoral infections. In a mouse virulence test the two strains of $B$. endodontalis studied produced an inflammation pattern which was different from the inflammation patterns found with strains of $B$. gingivalis and $B$. asaccharolyticus (18), suggesting a pathogenic potential different from that demonstrated by $B$. gingivalis and $B$. asaccharolyticus strains.

$B$. endodontalis can be easily distinguished from $B$. gingivalis; $B$. gingivalis hemagglutinates sheep erythrocytes (15), produces phenylacetic acid (8), and shows a strong trypsinlike activity, whereas $B$. endodontalis does not. It is more difficult to distinguish $B$. endodontalis from $B$. asaccharolyticus. Other than by DNA hybridization, $B$. endodontalis can be distinguished from $B$. asaccharolyticus by the lower guanine-plus-cytosine content of its DNA, by serological methods, and by electrophoretic patterns of proteins. The three strains of $\boldsymbol{B}$. endodontalis described in this paper grew very slowly both in broth and on enriched blood agar plates. Although growth was slow compared with almost all strains of $B$. gingivalis and $B$. asaccharolyticus, it is probably inappropriate to use this as a differential character. The three strains of $B$. endodontalis described here required menadione for growth, whereas six tested strains of $B$. asaccharolyticus, including the type strain, did not. Although more strains should be examined, menadione requirement might be a valuable test for identification of $B$. endodontalis.

\section{LITERATURE CITED}

1. Coykendall, A. L., F. S. Kaczmarek, and J. Slots: 1980 . Genetic heterogeneity in Bacteroides asaccharolyticus (Holdeman and Moore, 1970, Finegold and Barnes, 1977, Approved Lists, 1980) and proposal of Bacteroides gingivalis $\mathrm{sp}$. nov. and Bacteroides macacae (Slots and Genco) comb. nov. Int. J. Syst. Bacteriol. 30:559-564.

2. Finegold, S. M., and E. M. Barnes. 1977. Report of the ICSB Taxonomic Subcommittee on Gram-Negative Anaerobic Rods. Proposal that the saccharolytic and asaccharolytic strains at present classified in the species Bacteroides melaninogenicus (Oliver and Wherry) be reclassified into two species as Bacteroides melaninogenicus and Bacteroides asaccharolyticus. Int.
J. Syst. Bacteriol. 27:288-291.

3. Gisslow, M. T., and B. C. McBride. 1975. A rapid sensitive collagenase assay. Anal. Biochem. 68:70-78.

4. Holdeman, L. V., E. P. Cato, and W. E. C. Moore (ed). 1977. Anaerobe laboratory manual, 4th ed. Virginia Polytechnic Institute and State University, Blacksburg.

5. Holdeman, L. V., and J. L. Johnson. 1982. Description of Bacteroides loeschii sp. nov. and emendation of the descriptions of Bacteroides melaninogenicus (Oliver and Wherry) Roy and Kelly 1939 and Bacteroides denticola Shah and Collins 1981. Int. J. Syst. Bacteriol. 32:399-409.

6. Holdeman, L. V., and W. E. C. Moore. 1970. Bacteroides. p. 33-44. In E. P. Cato, C. S. Cummis, L. V. Holdeman, J. L. Johnson, W. E. C. Moore, R. M. Smibert, and L. D. Smith (ed.), Outline of clinical methods in anaerobic bacteriology, 2nd rev. Virginia Polytechnic Institute and State University, Blacksburg.

7. Johnson, J. L., and L. V. Holdeman. 1983. Bacteroides intermedius comb. nov. and descriptions of Bacteroides corporis $\mathrm{sp}$. nov. and Bacteroides levii sp. nov. Int. J. Syst. Bacteriol. 33:15-25.

8. Kaczmarek, F. S., and A. L. Coykendall. 1980. Production of phenylacetic acid by strains of Bacteroides asaccharolyticus and Bacteroides gingivalis (sp. nov). J. Clin. Microbiol. 12:288290.

9. Mayrand, D., and B. C. McBride. 1980. Ecological relationships of bacteria involved in a simple mixed anaerobic infection. Infect. Immun. 27:44-50.

10. Mayrand, D., B. C. McBride, T. Edwards, and S. Jensen. 1980. Characterization of Bacteroides asaccharolyticus and B. melaninogenicus oral isolates. Can. J. Microbiol. 26:1178-1183.

11. Moore, W. E. C., D. E. Hash, L. V. Holdeman, and E. P. Cato. 1980. Polyacrylamide slab gel electrophoresis of soluble proteins for studies of bacterial floras. Appl. Environ. Microbiol. 39:900-907.

12. Mouton, C., P. G. Hammond, J. Slots, M. J. Reed, and R. J. Genco. 1981. Identification of Bacteroides gingivalis by fluorescent antibody staining. Ann. Microbiol. (Paris) 132B:69-83.

13. Shah, H. N., and M. D. Collins. 1981. Bacteroides buccalis sp. nov., Bacteroides denticola sp. nov. and Bacteroides pentasaceous sp. nov., new species of the genus Bacteroides from the oral cavity. Zentralbl. Bakteriol. Parasitenkd. Infektionskr. Hyg. Abt. 1 Orig. Reihe C 2:235-241.

14. Slots, J. 1981. Enzymatic characterization of some oral and nonoral gram-negative bacteria with the API ZYM system. J. Clin. Microbiol. 14:288-294.

15. Slots, J., and R. J. Genco. 1979. Direct hemagglutination technique for differentiating Bacteroides asaccharolyticus oral strains from non-oral strains. J. Clin. Microbiol. 10:371-373.

16. Steffen, E. K., and D. J. Hentges. 1981. Hydrolytic enzymes of anaerobic bacteria isolated from human infections. J. Clin. Microbiol. 14:153-156.

17. van Steenbergen, T. J. M., J. J. de Soet, and J. de Graaff. 1979. DNA base composition of various strains of Bacteroides melan. inogenicus. FEMS Microbiol. Lett. 5:127-130.

18. van Steenbergen, T. J. M., P. Kastelein, J. J. A. Touw, and J. de Graaff. 1982. Virulence of black-pigmented Bacteroides strains from periodontal pockets and other sites in experimentally induced skin lesions in mice. J. Periodontal Res. 17:41-49.

19. van Steenbergen, T. J. M., C. A. Vlaanderen, and J. de Graaff. 1981. Confirmation of Bacteroides gingivalis as a species distinct from Bacteroides asaccharolyticus. Int. J. Syst. Bacteriol. 31:236-241.

20. van Steenbergen, T. J. M., C. A. Vlaanderen, and J. de Graaff. 1982. Deoxyribonucleic acid homologies among strains of $\mathrm{Bac}$ teroides melaninogenicus and related species. J. Appl. Bacteriol. 53:269-276. 